\title{
Immunomodulating Effects of Peptidic Fractions Issued from Milk Fermented with Lactobacillus helveticus
}

\author{
J. G. LeBlanc, ${ }^{\star} †$ C. Matar, ${ }^{\star}$ J. C. Valdéz,† J. LeBlanc, ${ }^{\star}$ and G. Perdigon†” \\ *Département de Chimie et Biochimie, \\ Université de Moncton, Moncton, NB, Canada E1A 3E9 \\ †Facultad de Bioquimica, Quimica y Farmacia, \\ Universidad Nacional de Tucuman, San Miguel de Tucuman, Argentina T4000INJ \\ $\ddagger$ Centro de Referencia para Lactobacilos (CERELA), \\ San Miguel de Tucuman, Argentina T4000ILC
}

\section{ABSTRACT}

The effect of peptides released during the fermentation of milk on the humoral immune system and on fibrosarcoma growth was studied. Lactobacillus helveticus was able to release peptidic compounds during milk fermentation due to its high proteolytic activity, as was shown by the degree of proteolysis and size-exclusion HPLC elution profiles. Three fractions of these compounds were separated and fed to mice during different periods $(2,5$, and $7 \mathrm{~d})$. The humoral immune response was assessed by following the number of IgA-secreting cells, and the antitumor activity was monitored by studying the regression of subcutaneously implanted fibrosarcomas. Feeding during 2 and $7 \mathrm{~d}$ with the medium-sized fraction (Fraction II) significantly increased the IgA-producing cells in the intestines, whereas feeding with the large compound fraction (Fraction I) during $5 \mathrm{~d}$ and the small compound fraction (Fraction III) during all three feeding periods provided similar increases. A double dose of Fraction II showed the highest IgAproducing cell count. The increase by Fraction III was shown to be caused by the presence of L-Tryptophan. Fraction II significantly decreased the size of fibrosarcoma when previously fed during $7 \mathrm{~d}$, and feeding with Fraction I during $5 \mathrm{~d}$ decreased significantly its size after $35 \mathrm{~d}$ of growth. Although the mechanisms by which lactic acid bacteria enhance the immune system are not clear, this study clearly shows that bioactive compounds released in fermented milks contribute to the immunoenhancing and antitumor properties of these products. The release of bioactive peptides by lactic acid bacteria can have important implications on the modulation of the cellular immune response.

(Key words: fermented milk, bioactive peptides, lactic acid bacteria, immunomodulation)

Received October 25, 2001

Accepted April 4, 2002

Corresponding author: C. Matar; e-mail: matarc@umoncton.ca.
Abbreviation key: GALT = gut-associated lymphoid tissue, $\mathbf{L A B}$ = lactic acid bacteria.

\section{INTRODUCTION}

Bioactive peptides encrypted in milk proteins can be released by enzymatic proteolysis, gastrointestinal digestion, or food processing. These peptides can exert a wide range of effects, such as antimicrobial, antihypertensive, antithrombotic, immunomodulatory, and opioid properties, in addition to aiding in the mineral absorption of calcium.

Lactic acid bacteria (LAB) utilize milk proteins, principally the caseins, as their prime source of essential and growth-stimulating amino acids (Juillard et al., 1998). These cells possess cell-envelope-located proteinases, which cause the degradation of caseins into oligopeptides; peptide transport systems, which allow the internalization of the released oligopeptides; and intracellular peptidases, which hydrolyze the oligopeptides into smaller peptides or into amino acids, which can then be used by the cell (Juillard et al., 1998; Kunji et al., 1998). The transport system of LAB enables them to internalize oligopeptides up to 18 amino acids in length, although rarely above 10 amino acids (Kunji et al., 1998). This allows the longer oligopeptides to be a source of bioactive peptides when further degraded by gastrointestinal enzymes or by intracellular peptidases of lysed lactic acid bacteria (Law and Haandrikman, 1997). Also, not all of the smaller oligopeptides are ingested by the LAB, permitting them to exert their effect. It has recently been shown that only $25 \%$ of the liberated oligopeptides were transported into the cells (Foucaud and Juillard, 2000).

The peptidic profile of milk proteins is significantly different after microbial fermentation, suggesting that microbial proteolysis can be a potential source of bioactive peptides (Matar et al., 1996). It has been shown that milk fermented by Lactobacillus helveticus R389, a bacteria that has strong protease and peptidase activities, as compared with other LAB (Moineau and Goulet, 
1991), is capable of exerting an antimutagenic effect while its protease-deficient derivative does not exert this effect (Matar et al., 1997). Other studies have shown that a proteinase from $L$. helveticus CP790 was able to release an antihypertensive peptide from casein hydrolysates (Yamamoto et al., 1994; Maeno et al., 1996).

Feeding mice with milks fermented by LAB has led to significant increases in various immune responses, such as sIgA-producing cells, macrophage activity, and specific antibody responses during infections (Perdigon et al., 1999). This study was elaborated to verify the biological effects of peptides released during milk fermentation on the stimulation of the immune system and on the inhibition of fibrosarcoma tumors in vivo. Milk fermented with L. helveticus R389 was separated and fractioned by size-exclusion HPLC. Three fractions, containing compounds of different molecular weights released by the proteolytic activity of $L$. helveticus, were then tested in vivo. The results of this investigation could help provide alternative or additional explications of the health-promoting properties of milk fermented by LAB, showing that the proteolytic activity of these bacteria can release compounds exerting biological activities.

\section{MATERIALS AND METHODS}

\section{Milk Fermentation}

Nonfat, dried, low-heat grade milk without vitamins A and D added (Dairytown Products Ltd., Sussex, NB, Canada) was rehydrated ( $12 \% \mathrm{wt} / \mathrm{vol})$ then autoclaved $\left(121^{\circ} \mathrm{C}\right.$ for 15 min; Sanyo Vertical Labo Autoclave, NB Scientific, Edison, NJ). The prepared milk was inoculated with $L$. helveticus R389 (2\% vol/vol) and incubated at $37^{\circ} \mathrm{C}$ for $17 \mathrm{~h}$. The inoculum was added to rehydrated milk prepared in the same manner $(2 \% \mathrm{vol} / \mathrm{vol})$ to start the milk fermentation. Fermentation was achieved using a 3-L Bioflow 3000 Biofermentor (NB Scientific, Edison, NJ) with an agitation rate of $100 \mathrm{rpm}, \mathrm{pH}$ control (maintained at $\mathrm{pH} 6.00$ by automatic addition of $4 \mathrm{~N} \mathrm{NaOH}$ when required), and $\mathrm{CO}_{2}$ spurging (10 psi, $0.2 \mathrm{~L} / \mathrm{min}$ ). Lactobacilli growth was determined by counting colony-forming units (cfu) after plating serial dilutions on MRS agar (Becton Dickinson, Cockeysville, $\mathrm{MD}$ ) and incubation at $37^{\circ} \mathrm{C}$ for $48 \mathrm{~h}$. The extent of milk protein proteolysis was evaluated using the $o$-phtaldialdehyde test (Church et al., 1983) and expressed as milliequivalents of $\mathrm{NH}_{3}$ per milliliter.

\section{Peptidic Fraction Separation and Collection}

Fractions were obtained by high-performance sizeexclusion chromatography using an HP1100 HPLC sys- tem (Agilent Technologies, Mississauga Ont., Canada). Milk samples were prepared prior to HPLC injection by centrifugation $\left(6000 \times g\right.$, for $20 \mathrm{~min}$ at $4^{\circ} \mathrm{C}$; Micromax RF, IEC, Fisher Scientific, Nepean, Ontario, Canada). The supernatant was filtered using a $0.22-\mu \mathrm{m}$ MillexGP seringe filter (Millipore, Fisher Scientific, Nepean, Ontario, Canada) and maintained at $4^{\circ} \mathrm{C}$ until injection. $200 \mu \mathrm{l}$ of the sample was loaded on a LKB TSKG2000SW gel filtration column $(600 \times 7.5 \mathrm{~mm}$, Agilent Technologies, Mississauga, Ont., Canada) using $5 \mathrm{mM}$ ammonium acetate ( $\mathrm{pH}$ 6.5, Fisher Scientific, Nepean, Ontario, Canada) as the elution buffer, prepared as described previously (Lemieux et al., 1991). The flow rate was $0.7 \mathrm{ml} / \mathrm{min}$, and the eluted proteins were monitored at 214, 220, 224 and $280 \mathrm{~nm}$ using an HP1100 Diode Array Detector (Agilent Technologies, Mississauga, Ont., Canada). Fractions were collected with a Gilson FC104 Fraction Collector (VWR International Mississauga, Ont., Canada), then pooled and concentrated using an Automatic Environnemental SpeedVac System (AES1010; Fisher Scientific, Nepean, Ontario, Canada) and stored at $4^{\circ} \mathrm{C}$ until their use during in vivo studies. Protein concentration was determined using the Bradford assay (Bio-Rad Laboratories, Mississauga, Ont., Canada). Reversed-phase HPLC was performed as described previously (Matar and Goulet, 1996) using a 3.5- $\mu \mathrm{m}$ Zorbaz SB-C18 column $(4.6 \times 150$ mm; Agilent Technologies, Mississauga, Ont., Canada). Fractions were selected based on elution time/appearance of major peaks and were referred to as Fraction I, II, and III for large, medium, and small peptides, respectively.

\section{Immune System Stimulation Studies}

The immunomodulating effect was determined by histochemical and immunofluorescence assays using the in vivo model developed by Perdigon et al. (1993). Twenty-five to $30 \mathrm{~g}$ BALB/c mice were assigned randomly to one of three subgroups corresponding to three different lengths of feeding: 2, 5, or $7 \mathrm{~d}$. Two different sets of mice were used during the experimentation: one was dedicated to the IgA studies and the second one to tumor studies. Each mouse was given $50 \mu \mathrm{g}$ of one of the three peptidic fractions resuspended in $50 \mu \mathrm{L}$ of sterile water (or $50 \mu \mathrm{L}$ of sterile water for the control group) per day of feeding for the length of the feeding period. The amount of $50 \mu \mathrm{g}$ of protein/day for a given fraction is administered orally for the groups of mice, or $100 \mu \mathrm{g}$ when a double dose is used. Each subgroup (including the control group) contained a minimum of five mice, and each study was repeated twice independently. Mice were allowed free access to distilled water and to constant-nutrient formula commercial diet (bal- 
anced/autoclaved Rodent Diet; Charles River Laboratories, Saint-Constant, QC, Canada). The small intestine and the bronchial tissues were removed and washed repeatedly with phosphate-buffered saline. Tissues were prepared for histological evaluation using standard methods (Sainte-Marie, 1962). Serial paraffin sections of $4 \mu \mathrm{m}$ were made and used for the immunofluorescence assay.

\section{Immunofluorescence Assay}

The number of cells secreting IgA was determined by direct immunofluorescence assay as described previously (Sainte-Marie, 1962). The sections were incubated with $\alpha$-chain monospecific antibody conjugated with fluorescein isothiocyanate (Sigma, St. Louis, MO), and the number of fluorescent cells was counted in 30 fields of vision as seen with $1000 \times$ magnification using a Hund H600 reflected fluorescent light microscope (charles Rivers Laboratories). The results were expressed as cells in 10 fields of vision.

\section{Induction of Fibrosarcoma Tumor}

The fibrosarcoma tumors were induced by subcutaneous implantation of methylcholanthrene crystals and maintained by serial passage in vivo. Transplants were made by the subcutaneous inoculation of $5 \times 10^{5}$ viable tumor cells into the left flank of mice receiving distilled water by gavage (control) or Fraction I or II by gavage (Valdez and Perdigon, 1991). The control and Fraction I or II were given to the mice prior to the fibrosarcoma inoculation. The tumor volumes were recorded up to 30 d. During this period, mice were fed a conventional balanced diet ad libitum. Tumor growth was evaluated by caliper measurement of tumor length and width. Tumor volume was determined using the formula $\mathrm{V}=$ $0.4 \times \mathrm{d}^{2} \times \mathrm{D}$, where $\mathrm{V}$ is the volume in $\mathrm{ml}$, and $\mathrm{d}$ and $\mathrm{D}$ are the longest and shortest diameters, respectively. The tumors became visible and palpable after approximately $10 \mathrm{~d}$.

\section{Statistical Analysis}

Results were expressed as mean \pm standard deviation, and their significance was analyzed using the Student's $t$ test.

\section{RESULTS}

\section{Milk Fermentation}

L. helveticus was able to hydrolyze milk proteins and cause the release of peptides, as shown by the level of
A)

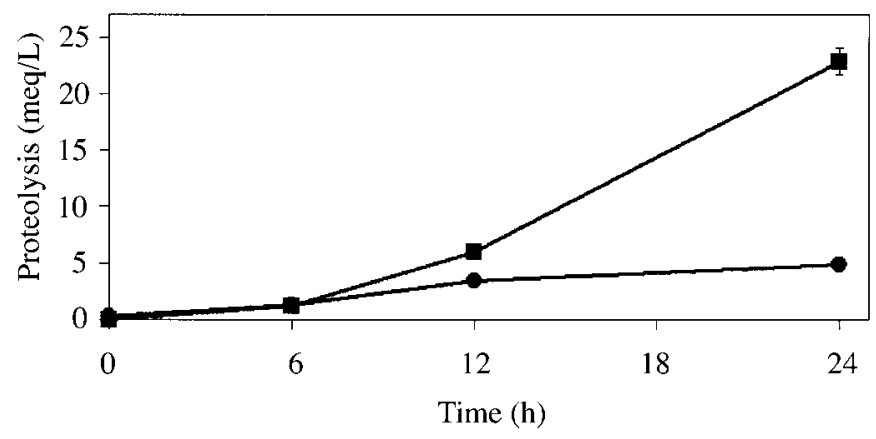

B)

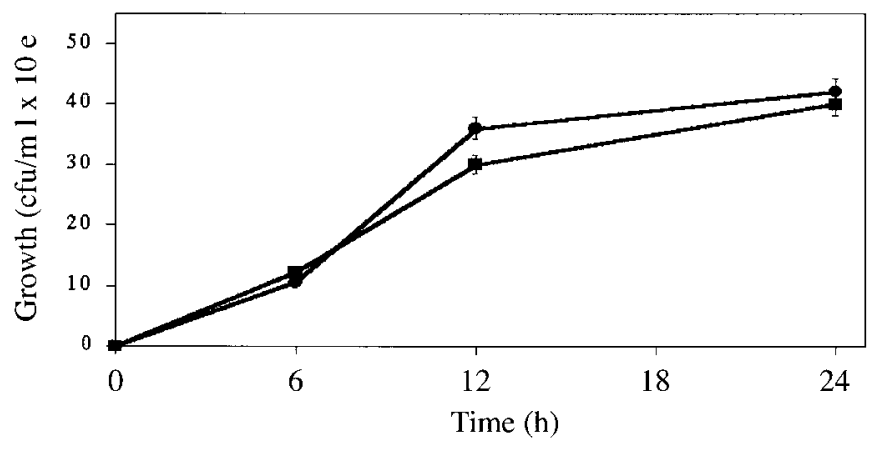

Figure 1. Degree of proteolysis (A) and growth (B) of milk fermented with Lactobacillus helveticus at $37^{\circ} \mathrm{C}$ without $\mathrm{pH}$ control (circle) and at pH 6.0 (square). Data is the mean of four independent fermentations.

proteolysis (Figure 1) and HPLC elution pattern of milk after fermentation (Figure 2). The degree of proteolysis was clearly more pronounced at $\mathrm{pH} 6.0$ than without $\mathrm{pH}$ control (Figure 1A). This change in proteolytic activity is caused by the increase in activity of LAB proteases at pH 6.0 (Frey et al., 1986) and not by changes in growth since $\mathrm{pH}$ control did not influence the numbers of $L$. helveticus present (Figure 1B). The degradation of milk proteins seen by the proteolysis of $L$. helveticus was confirmed by size-exclusion HPLC. The fermentation of milk by this LAB increased the amount of smaller-weight protein-derived compounds by the degradation of milk proteins. This is shown by the appearance of peaks after milk fermentation (Figure 2B) that were not present before (Figure 2A).

\section{Effect of Peptidic Fractions on Number of $\lg A^{+} B$ CellsAssociated with the Gut-associated Lymphoid Tissue}

The RP-HPLC profile of Fraction III and the firstand second-order derivative of its major peak shows the 
A)

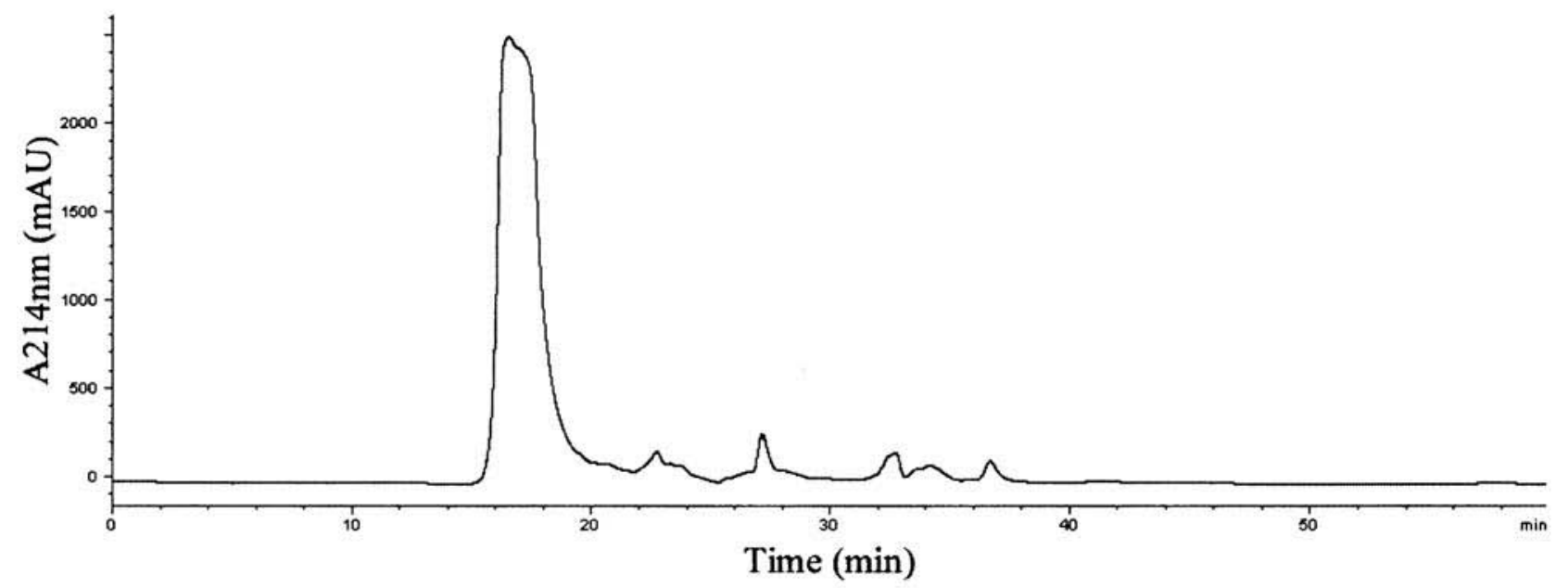

B)

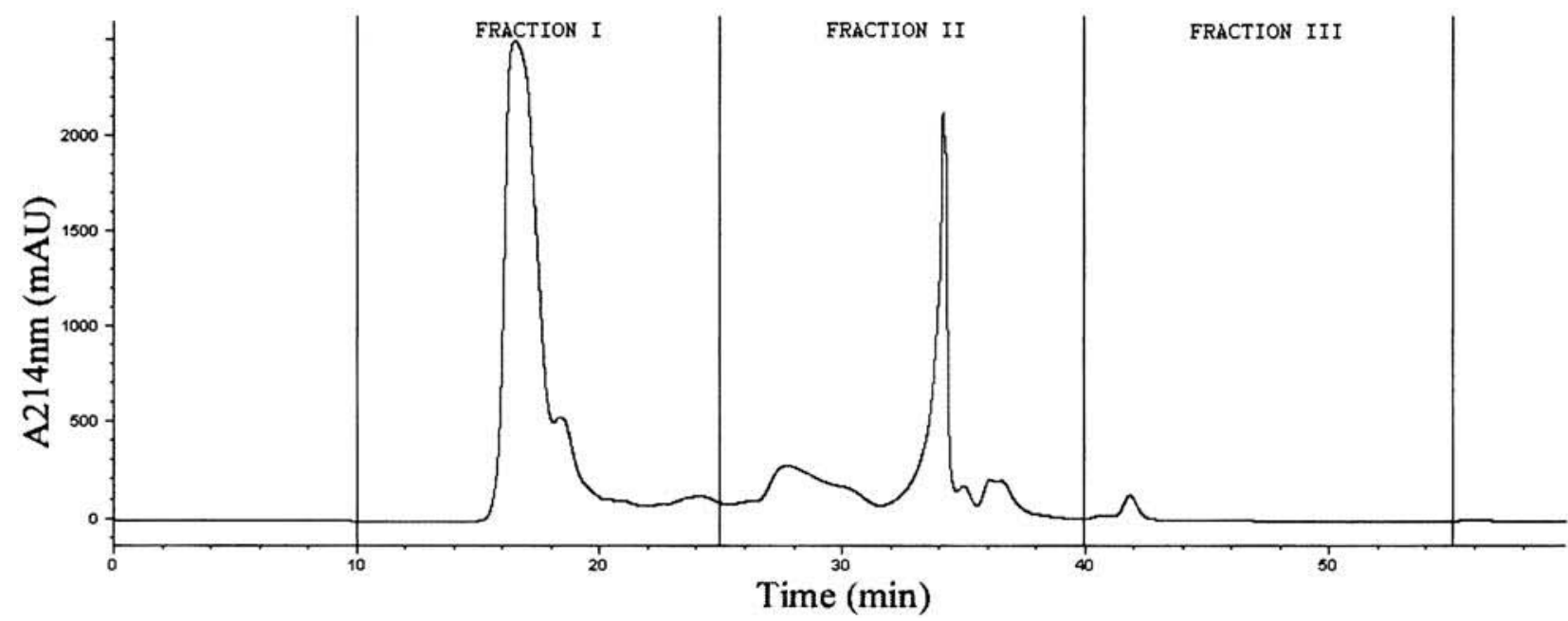

Figure 2. Size-exclusion HPLC profile of unfermented milk (A) and milk fermented with Lactobacillus helveticus R389 for 24 h (B).

probable presence of tryptophan (Figure 3 ). As shown in Figure 4, the peptidic fractions increased the number of $\mathrm{IgA}^{+} \mathrm{B}$ cells at the level of the gut-associated lymphoid tissue (GALT). Fraction III significantly increased the number of $\operatorname{IgA}^{+} \mathrm{B}$ cells after all three feeding periods $(2,5$, and $7 \mathrm{~d})$. Thus, the tryptophan effect was studied on IgA $\mathrm{A}^{+} \mathrm{B}$ cells, and it was shown to have a stimulatory effect on their number after $7 \mathrm{~d}$ of feeding $\left(97 \pm 4 \mathrm{IgA} \mathrm{A}^{+}\right.$ cells/10 fields of vision). Fraction II increased the number of IgA $\mathrm{A}^{+} \mathrm{B}$ cells to significant levels after $2 \mathrm{~d}$ of feeding (103 \pm 4$)$ and $7 \mathrm{~d}$ of feeding (100 \pm 4 ), and a double dose of this peptidic fraction fed for $7 \mathrm{~d}$ significantly increased the number of $\operatorname{IgA}^{+} \mathrm{B}$ cells $(116 \pm 4)$ compared with the normally fed mice $(81 \pm 4)$ and with mice fed with normal concentration of Fraction II (100 \pm 4$)$. Feeding with Fraction I slightly increased the number of $\mathrm{IgA}^{+} \mathrm{B}$ cells after 2 and $5 \mathrm{~d}$ of feeding but dropped to insignificant amounts after $7 \mathrm{~d}$.

\section{Determination of the Antitumor Effect and Inhibition of Fibrosarcoma in Mice}

The effect of oral administration of peptidic fractions on the suppression of the growth of methylcholantreneinduced fibrosarcoma was followed by determination of the tumor volume over a period of $35 \mathrm{~d}$. These results 
A)

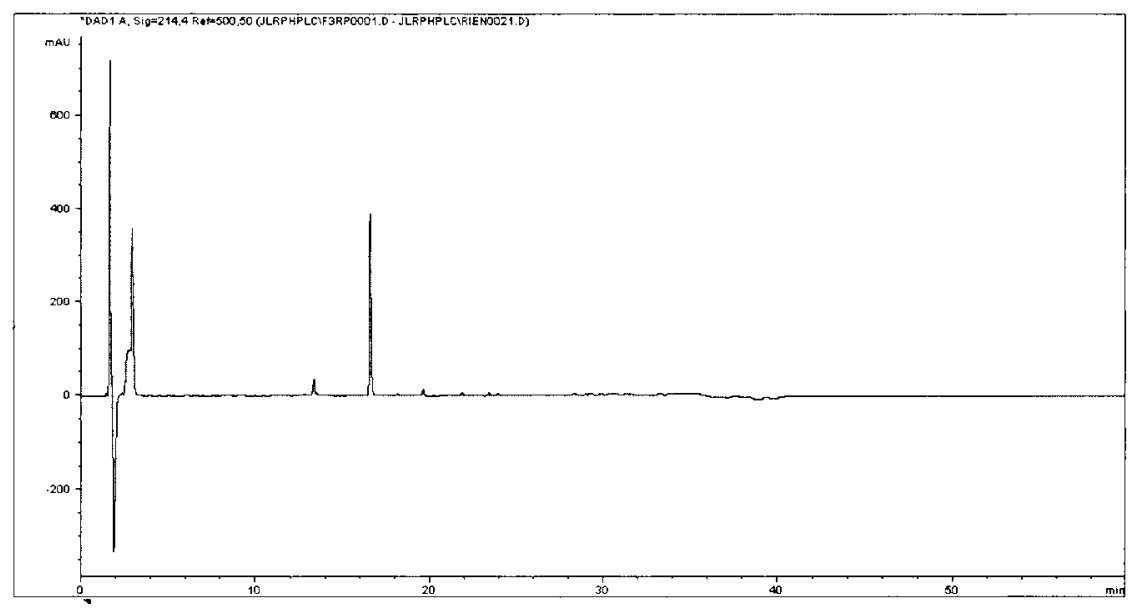

B)

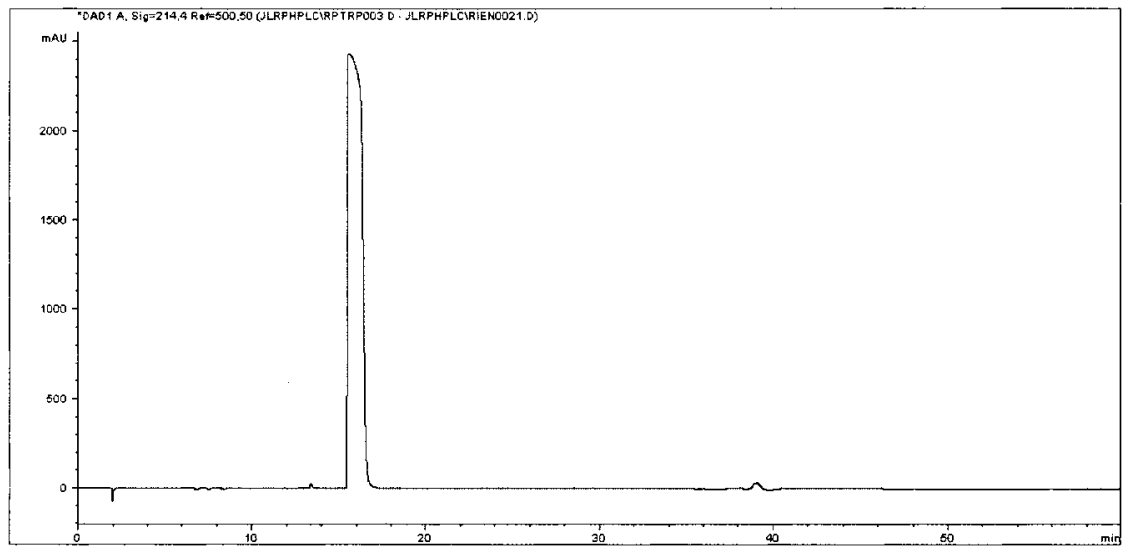

C)

D)

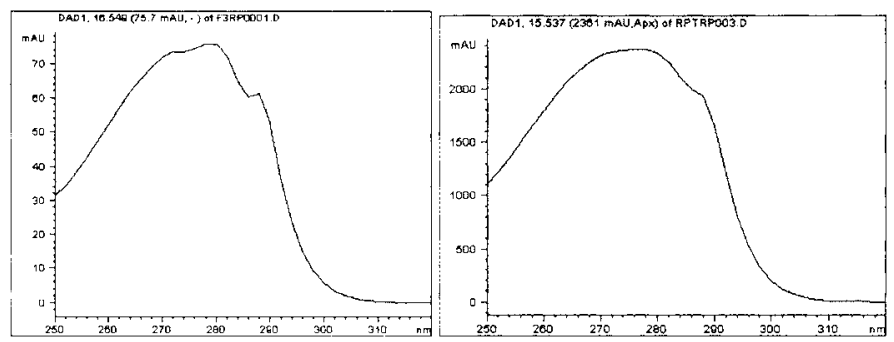

E)

F)

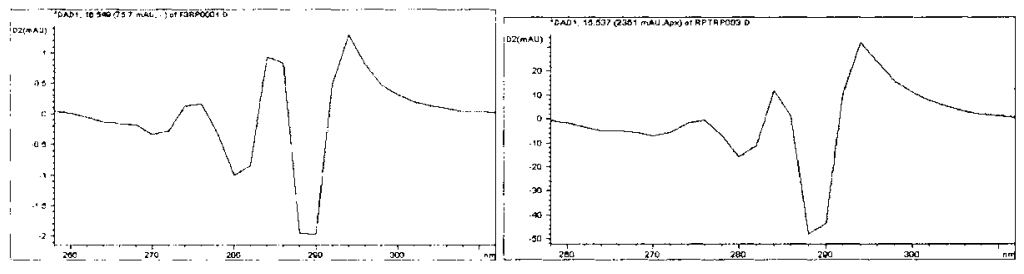

Figure 3. Reverse-phase HPLC of Fraction III (A) and pure tryptophan (B), first-order derivative of the major peak of Fraction III (C) and pure tryptophan (D), and second-order derivative of the major peak of Fraction III (E) and pure tryptophan (F). 
A)

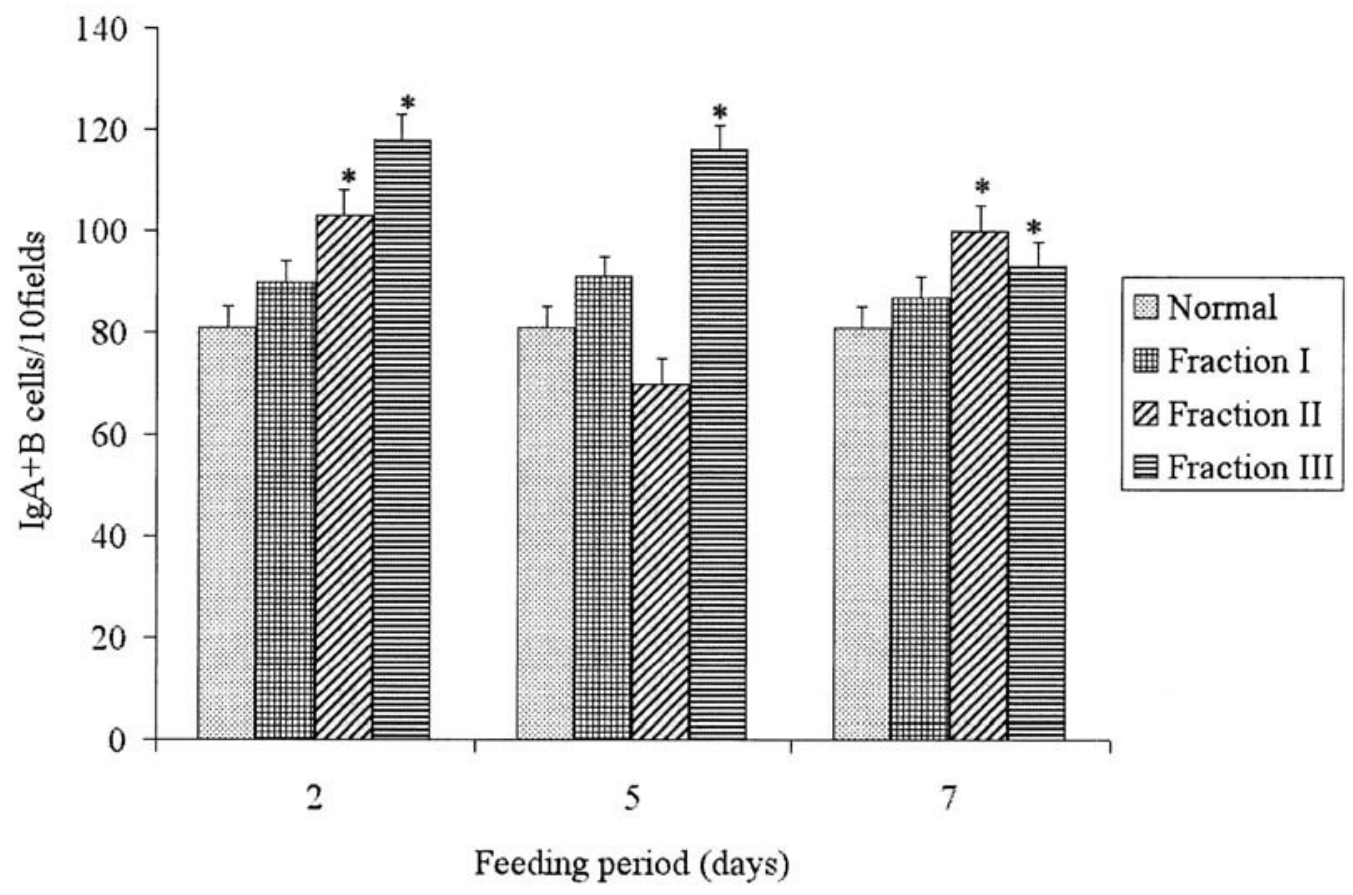

B)

C)
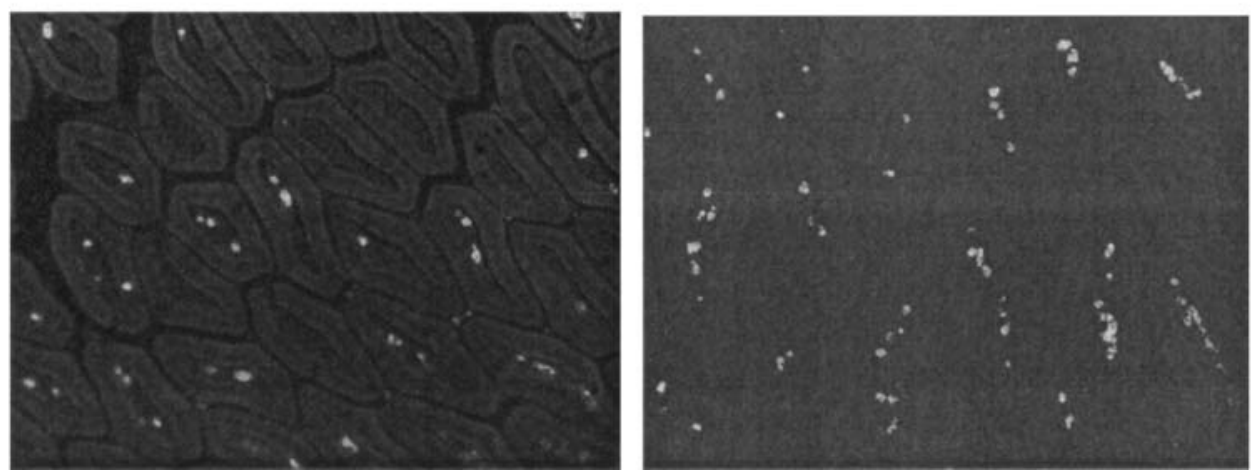

Figure 4. Effect of previous feeding with peptidic fractions on $\operatorname{IgA}^{+} \mathrm{B}$ cells. Immunofluorescent IgA+ cells (green) in the small intestine

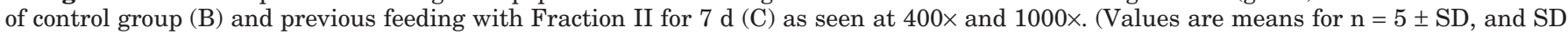
from the corresponding values for control: $* P<0.05$; $* * P<0.01$.)

are shown in Figure 5. In all cases, the feeding of mice with the peptidic fractions was terminated $10 \mathrm{~d}$ prior to the subcutaneous inoculation of fibrosarcomas.

The most remarkable effect on fibrosarcoma growth was its inhibition after $7 \mathrm{~d}$ previous feeding with Fraction II (Figure 5B). The tumor, after feeding with this peptidic fraction, was smaller throughout its growth when compared to the normally fed control group, and this difference became significant at d 22 of tumor growth and remained as such for the duration of the study. Feeding mice with Fraction I for $5 \mathrm{~d}$ decreased the size of the tumor, but only significantly after 35 $\mathrm{d}$ growth (Figure 5A). All other feeding periods with fractions did not affect the growth of fibrosarcoma.

\section{DISCUSSION}

L. helveticus is commonly used in the manufacture of Swiss-type cheese and other fermented milk products. 
A)

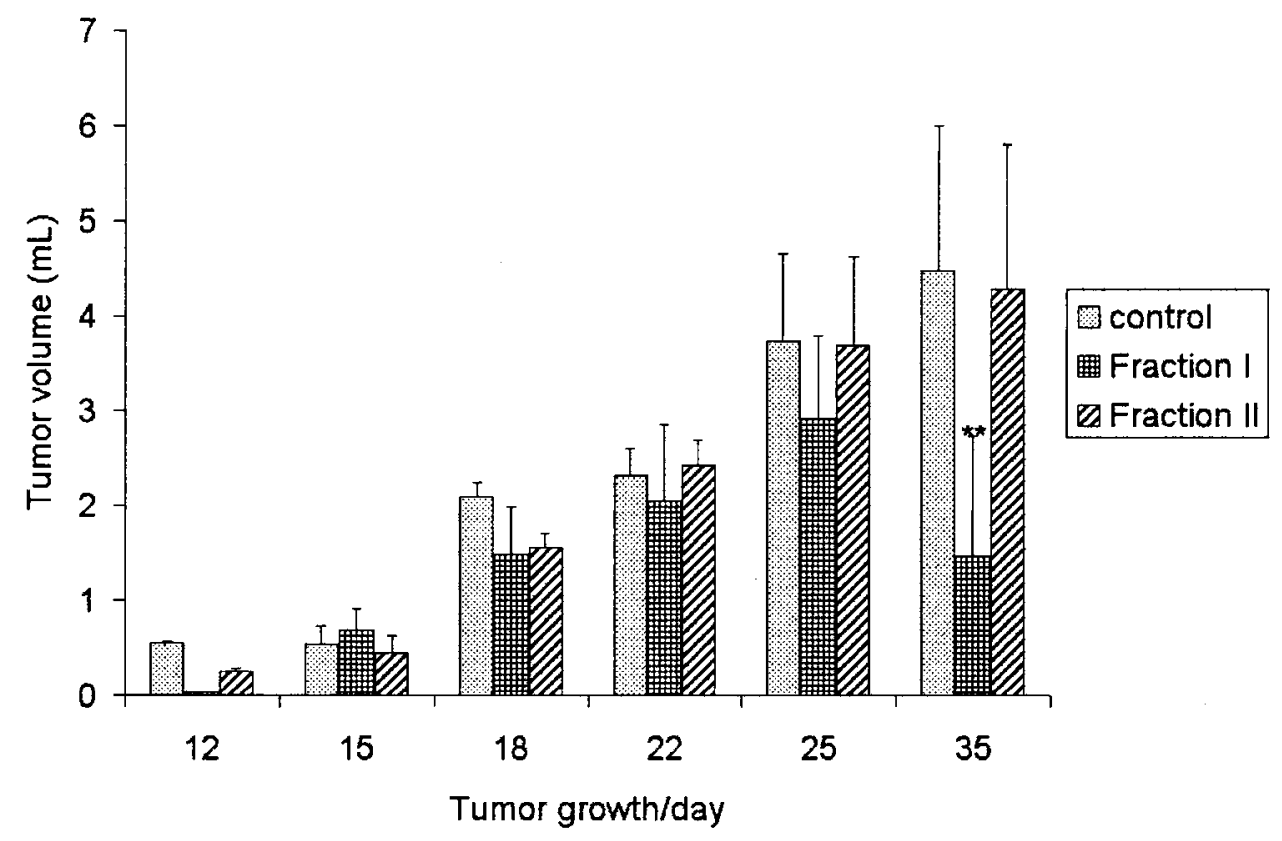

B)

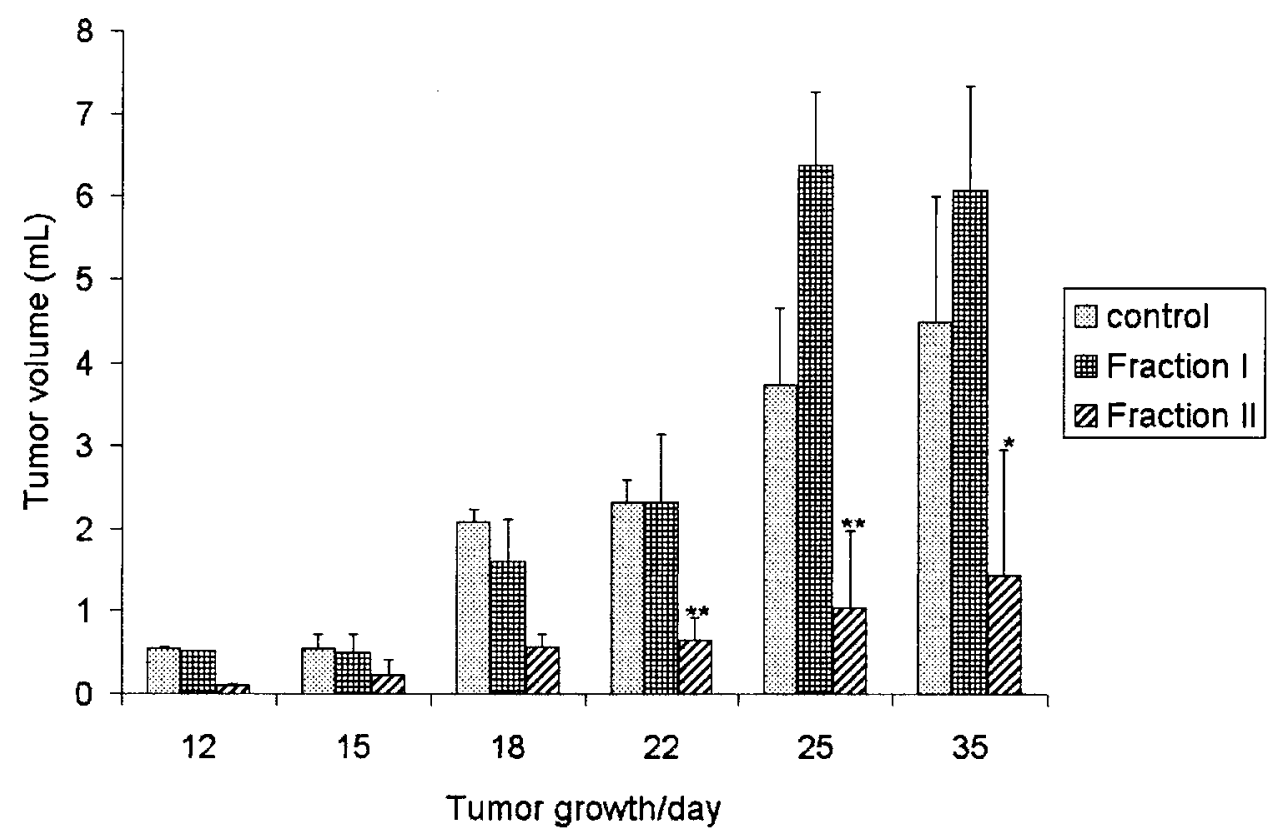

Figure 5. Effect of 5 (A) and $7 \mathrm{~d}$ (B) previous feeding with peptidic fractions on fibrosarcoma growth. Mice were given diets supplemented with either Fraction I or II or the control for 5 and $7 \mathrm{~d}$ prior to the inoculation of $5 \times 10^{5}$ tumour cells. The volume and the growth of the methylcholantrene-induced fibrosarcoms were recorded for 12, 15, 18, 22, 25 and $35 \mathrm{~d}$. The controls are animals given distilled water by gavage with a conventional diet after inoculation of tumours. (Values are means for $\mathrm{n}=5 \pm \mathrm{SD}$ and SD from the corresponding values for control: $* P<0.05 ; * * P<0.01$.) 
Milks fermented with $L$. helveticus have been shown to possess antihypertensive peptides (Yamamoto et al., 1994 and 1999; Maeno et al., 1996), antimutagenic properties (Matar et al., 1997), immunomodulating effects on lymphocyte proliferation in vitro (Laffineur et al., 1996), and the ability to stimulate the phagocytic activity of pulmonary macrophages (Moineau and Goulet, 1991). These LAB are known to have high proteolytic activities (Luoma et al., 2001), causing the release of oligopeptides from digestion of milk proteins (Foucaud and Juillard, 2000). These oligopeptides can be a direct source of bioactive peptides following hydrolysis by gastrointestinal enzymes. Several casein-derived peptides may play a role in the modulation of the immune system. Fragments of $\beta$-casein have been shown to stimulate phagocytosis of sheep red blood cells by peritoneal macrophages, protect against infections (Migliore-Samour et al., 1989), enhance the proliferation of human peripheral blood lymphocytes in vitro (Kayser and Meisel, 1996), and increase proliferation of murine peripheral blood lymphocytes in vivo (Coste et al., 1992). A pepsin-generated hydrolysate of lactoferrin has been shown to contain immunostimulating peptides, which can enhance the proliferation of spleen cells and can stimulate the phagocytic activity of human neutrophils (Miyauchi et al., 1998).

The goal of this investigation was to study the effect of peptides released during the fermentation of milk by L. helveticus R389 on the systematic immune system and on the growth of fibrosarcomas. To grow in milk, $\mathrm{LAB}$ must be able to hydrolyze the large proteins contained in milk. As previously found (Matar et al., 1996), L. helveticus was able to release oligopeptides due to its high proteolytic activity (Figure 1A). The appearance of smaller molecular weight compounds as seen by the HPLC elution profile after fermentation (Figure 2B) confirmed the proteolysis results.

The intestinal mucosa is the body's first line of host defense against pathogenic invasions from food. After ingestion, orally administered antigens encounter the GALT, which is a well-organized immune network that protects the host from pathogens and prevents ingested proteins from hyperstimulating the immune response through a mechanism called oral tolerance (Weiner, 1997). The main mechanism of protection given by the GALT is humoral immune response mediated by IgAproducing cells and secretory IgA, which prevent the entry of potentially harmful antigens, while also interacting with mucosal pathogens without potentiating damage because it doesn't bind complement. The stimulation of this immune response could thus be used to prevent certain infectious diseases that enter the host through the oral route.
Fraction II fed during 2 or $7 \mathrm{~d}$ caused a significant increase in the number of $\operatorname{IgA}^{+} \mathrm{B}$ cells in the small intestine of mice, but this number decreased after $5 \mathrm{~d}$, possibly due to oral tolerance (Figure 4). Feeding with a double dose of this fraction for $7 \mathrm{~d}$ showed a large increase in the number of $\operatorname{IgA}^{+} \mathrm{B}$ cells as compared with a single dose, showing the importance of the dose on the stimulation of the immune system. There was also a significant increase in the number of $\operatorname{IgA}^{+} \mathrm{B}$ cells in the gut after feeding for $2 \mathrm{~d}$ with Fraction I, but the number dimished to insignificant amounts after feeding for longer periods (Figure 4). The cause of this decrease over time is probably oral tolerance since it is well documented that orally administered proteins induce systemic hyporesponsiveness to the fed protein (reviewed in Weiner, 1997).

Fraction III, which showed a significant increase in the $\operatorname{IgA}^{+} \mathrm{B}$ cells in the small intestine at all feeding periods (Figure 4), showed the potential presence of tryptophan (as an isolate amino acid or contained in a small peptide; Figure 3). Thus, the tryptophan effect was studied, and it was shown to increase the $\operatorname{IgA} \mathrm{A}^{+} \mathrm{B}$ cells after $7 \mathrm{~d}$ of feeding. It is known that tryptophan catabolism in macrophages due to interferon- $\gamma$-induced indoleamine 2,3-dioxygenase activation is able to suppress T-cell proliferation (Munn et al., 1999). Also noteworthy is the fact that the gastrointestinal tract of rats contains tryptophan 5-hydrolysase (TPH), an enzyme capable of synthesizing serotonin from tryptophan $(\mathrm{Yu}$ et al., 1999); thus TPH is able to diminish tryptophan and cause possible suppression of T-cell proliferation. The addition of tryptophan, the rarest and only amino acid whose level is specifically and selectively modified in response to infection and inflammation (Widner et al., 2000), could reverse the inhibition of T-cell proliferation by tryptophan catabolism, allowing the $\mathrm{T}_{\mathrm{H}} 2$ cells to help differentiate the B cells and increase their IgA production by cytokines. However, the supplementation of tryptophan is not recommended in vivo because of potential neurotoxic metabolites generated along the indoleamine 2,3-dioxygenase-induced tryptophan catabolic pathway (Widner and Fuchs, 2000).

The effect of feeding with the peptidic fractions would be restricted to the gut since there seemed not to be an activation of the IgA cycle due to an absence of an increase of the number of IgA secreting cells in the bronchial tissues (data not shown). This result is in contrast to our previous expectations since milk fermented with $L$. helveticus increased the number of $\operatorname{IgA}^{+}$ $\mathrm{B}$ cells in the small intestine and bronchial tissues while its protease deficient derivative did not (Matar et al., 2001). This lack of stimulation in the bronchial tissue could be dose-dependent, a result of oral tolerance, or due to the loss of some peptides following their separa- 
tion. Peptides have been shown to bind to native milk proteins by ionic interactions and thus can be protected from enzymatic degradation in the gastrointestinal tract or by endopeptidases of lysed LAB. These previously protected peptides may be absent following the ingestion of the peptidic fractions, thereby explaining an absence of IgA cycle activation.

The peptidic fractions inhibited the growth of fibrosarcoma, as was shown by a decrease in tumor volume as compared with normally fed mice (Figure 5). The most remarkable effect was the inhibition of tumor growth after $7 \mathrm{~d}$ of feeding with Fraction II. Fraction I decreased the growth of fibrosarcoma after $5 \mathrm{~d}$ of feeding only. This effect would be exerted by cytokines released from cells involved in the inflammatory immune response more than mediated by specific immune mechanisms since the IgA cycle was not induced (Perdigon et al., 1999). The bioactivity of Fraction I could be due to the open structure of caseins after enzyme attacks that enhance the possibility for a release of novel peptides normally hidden in the intact structure. Peptides released during fermentation could also bind to the proteins' surface before reaching the GI tract. In the latter case, the casein would act as a vehicle for such peptides.

The study of the effects of bioactive peptides on the immune system is only starting, and more research must be done in order to understand the complete mechanism of their action. By the production of bioactive peptides through the use of microbial sources, these findings will aid the development of new food-based products that help prevent infectious diseases and some types of cancer.

\section{ACKNOWLEDGMENTS}

This work was financially supported by the CONICET (Consejo Nacional de Investigaciones Científicas y Técnicas), IICA (Inter-American Institute for Cooperation on Agriculture) and the New Brunswick Departement for Agriculture and Rural Development (now the Department of Agriculture, Fisheries and Aquaculture).

\section{REFERENCES}

Church, F. C., H. E. Swaisgood, D. H. Porter, and G. L. Catignani. 1983. Spectrophotometric assay using o-phtaldialdehyde for determination of proteolysis in milk and isolated milk proteins. J. Dairy Sci. 66:1219-1227.

Coste, M., V. Rochet, J. Leonil, D. Molle, S. Bouhallab, and D. Tome. 1992. Identification of C-terminal peptides of bovine beta-casein that enhance proliferation of rat lymphocytes. Immunol. Lett. 33:41-46.

Foucaud, C., and V. Juillard. 2000. Accumulation of casein-derived peptides during growth of proteinase-positive strains of Lactococcus lactis in milk: Their contribution to subsequent bacterial growth is impaired by their internal transport. J. Dairy Res. 67:233-240.
Frey, J. P., E. H. Marth, M. E. Johnson, and N. F. Olson. 1986. Peptidases and proteases of lactobacilli associated with cheese. Milchwissenschaft 41:622.

Juillard, V., A. Guillot, D. Le Bars, and J. C. Gripon. 1998. Specificity of milk peptide utilization by Lactococcus lactis. Appl. Environ. Microbiol. 64:1230-1236.

Kayser, H., and H. Meisel. 1996. Stimulation of human peripheral blood lymphocytes by bioactive peptides derived from bovine milk proteins. FEBS Lett. 383:18-20.

Kunji, E. R., G. Fang, C. M. Jeronimus-Stratingh, A. P. Bruins, B. Poolman, and W. N. Konings. 1998. Reconstruction of the proteolytic pathway for use of beta-casein by Lactococcus lactis. Mol. Microbiol. 27:1107-1118.

Laffineur, E., N. Genetet, and J. Leonil. 1996. Immunomodulatory activity of beta-casein permeate medium fermented by lactic acid bacteria. J. Dairy Sci. 79:2112-2120.

Law, J., and A. Haandrikman. 1997. Proteolytic enzymes of lactic acid bacteria. Int. Dairy J. 7:1-11.

Lemieux, L., J. M. Piot, D. Guillochon, and J. Amiot. 1991. Study of the efficiency of a mobile phase used in size-exclusion HPLC for the separation of peptides from a casein hydrolysate according to their hydrodynamic volume. Chromatographia 31:499-504.

Luoma, S., K. Peltoniemi, and V. Joutsjoki. 2001. Expression of six peptidases from Lactobacillus helveticus in Lactococcus lactis. Appl. Environ. Microbiol. 67:1232-1238.

Maeno, M., N. Yamamoto, and T. Takano. 1996. Identification of an antihypertensive peptide from casein hydrolysate produced by a proteinase from Lactobacillus helveticus CP790. J. Dairy Sci. 79:1316-1321.

Matar, C., J. Amiot, L. Savoie, and J. Goulet. 1996. The effect of milk fermentation by Lactobacillus helveticus on the release of peptides during in vitro digestion. J. Dairy Sci. 79:971-979.

Matar C., and J. Goulet. 1996. B-Casomorphin 4 from milk fermented by a mutant of Lactobacillus helveticus. Int. Dairy J. 6:383-397.

Matar, C., S. S. Nadathur, A. T. Bakalinsky, and J. Goulet. 1997. Antimutagenic effects of milk fermented by Lactobacillus helveticus L89 and a protease-deficient derivative. J. Dairy Sci. 80:1965-1970.

Matar, C., J. C. Valdez, M. Medina, M. Rachid, and G. Perdigon. 2001. The implication of proteolysis during milk fermentation on enhancing the immune system and regression of fibrosarcomas. J. Dairy Res. 68:601-609.

Migliore-Samour, D., F. Floch, and P. Jolles. 1989. Biologically active casein peptides implicated in immunomodulation. J. Dairy Res. 56:357-362.

Miyauchi, H., S. Hashimoto, M. Nakajima, I. Shinoda, Y. Fukuwatari, and H. Hayasawa. 1998. Bovine lactoferrin stimulates the phagocytic activity of human neutrophils: Identification of its active domain. Cell Immunol. 187:34-37.

Moineau, S., and J. Goulet. 1991. Effect of fermented milks on humoral immune response in mice. Int. Dairy J. 1:231-239.

Munn, D. H., E. Shafizadeh, J. T. Attwood, I. Bondarev, A. Pashine, and A. L. Mellor. 1999. Inhibition of T cell proliferation by macrophage tryptophan catabolism. J. Exp. Med. 189:1363-1372.

Perdigon, G., M. E. de Jorrat, S. F. de Petrino, and M. Rachid. 1993. Antitumor activity of orally administerd Lactobacillus casei: Significance of its dose in the inhibition of a fibrosarcoma in mice. Food Agric. Immunol. 5:39-49.

Perdigon, G., E. Vintini, S. Alvarez, M. Medina, and M. Medici. 1999. Study of the possible mechanisms involved in the mucosal immune system activation by lactic acid bacteria. J. Dairy Sci. 82:1108-1114.

Sainte-Marie, G. 1962. A paraffin embedding technique for studies employing immunofluorescence. J. Histochem. Cytochem. 10:150-156.

Valdez, J. C., and G. Perdigon. 1991. Piroxicam, indomethacin and aspirin action on a murine fibrosarcoma. Effects on tumour-associated and peritoneal macrophages. Clin. Exp. Immunol. 86:315-321.

Weiner, H. L. 1997. Oral tolerance: Immune mechanisms and treatment of autoimmune diseases. Immunol. Today 18:335-343. 
Widner, B., and D. Fuchs. 2000. Immune activation and degradation of tryptophan. Mod. Asp. Immunobiol. 1:105-108.

Widner, B., G. Weiss, and D. Fuchs. 2000. Tryptophan degradation to control T-cell responsiveness. Immunol. Today 21:250.

Yamamoto, N., A. Akino, and T. Takano. 1994. Antihypertensive effect of the peptides derived from casein by an extracellular proteinase from Lactobacillus helveticus CP790. J. Dairy Sci. 77:917-922.
Yamamoto, N., M. Maeno, and T. Takano. 1999. Purification and characterization of an antihypertensive peptide from a yogurtlike product fermented by Lactobacillus helveticus CPN4. J. Dairy Sci. 82:1388-1393.

Yu, P. L., M. Fujimura, K. Okumiya, M. Kinoshita, H. Hasegawa, and M. Fujimiya. 1999. Immunohistochemical localization of tryptophan hydroxylase in the human and rat gastrointestinal tracts. J. Comp. Neurol. 411:654-665. 